$\begin{array}{llll}\text { MANAS Sosyal Araştırmalar Dergisi } & 2020 & \text { Cilt: } 9 & \text { Sayı: } 2 \\ \text { MANAS Journal of Social Studies } & 2020 & \text { Volume: } 9 & \text { No: } 2\end{array}$

Research Paper / Araştırma Makalesi

\title{
İşletme Yöneticilerinin Coğrafi İşaret Tesciline Yönelik Bakış Açıları: Gümüşhane İli Örneği ${ }^{1}$
}

\author{
Songül Seda KAMBER-TAŞ² ve Sedat TAŞ3
}

\section{$\ddot{O} z$}

$\mathrm{Bu}$ araştırma ile coğrafi işaretli ürün üretimi gerçekleştiren işletmecilerin coğrafi işaret tesciline ve tescil belgesi edinmeye yönelik bakış açılarının incelenmesi amaçlanmaktadır. Araştırmanın verileri, Gümüşhane'de bulunan sekiz farklı Gümüşhane Dut Pestili ve Gümüşhane Kömesi üreticisi olan işletme yöneticileriyle gerçekleştirilen yarı yapılandırllmış görüşme tekniğiyle 15-25 Ocak 2018 tarihleri arasında toplanmıştır. Gerçekleştirilen görüşmeler sonrasında, katılımcılardan yalnızca bir tanesinin işletmeleri adına coğrafi işaret tescil belgesi edindikleri sonucuna varılmıştır. Katılımcıların bir kısmı haksız rekabetin önüne geçmek, ürün kalitesini korumak, rekabet üstünlüğü sağlamak ve tüketiciye güven sunmak açısından tescil belgesinin faydalı olacağı görüşüne olumlu bakarken diğer katılımcıların aksi yönde görüşlere sahip oldukları sonucuna ulaşılmıştır.

Anahtar Kelimeler: Gastronomi, Coğrafi İşaretler, Coğrafi İşaretli Ürün Tescili, Gümüşhane Dut Pestili, Gümüşhane Kömesi

Perspectives of Business Managers on Geographical Indication Registration: Sample of Gumushane Province

\begin{abstract}
Purpose of this study is to analyses views of businesses with geographical indication product manufacturing to geographical indication registration and registration certificate. Study data are collected between 15-25 January 2018 with semi-structured interview from eight different Gümüşhane Dut Pestili (dried mulberry rollup) and Gümüşhane Kömesi (churchkhela) producer business managers in Gümüşhane. After these interviews, it is found that only one participant has geographical indication registration certification for business. While some participants have positive view that registration certificate can benefit to prevent unfair competition, protect products quality, achieve competitive advantage and ensure trust to consumer, others have opposite view.
\end{abstract}

Key Words: Gastronomy, Geographical Indicators, Geographical Indicated Product Registration, Gümüşhane Dried Mulberry Rollup, Gümüşhane Churchkhela

\section{Atıf İçin / Please Cite As:}

Kamber-Taş, S. S. ve Taş, S. (2020). İşletme yöneticilerinin coğrafi işaret tesciline yönelik bakış açıları: Gümüşhane ili örneği. Manas Sosyal Araștırmalar Dergisi, 9(2), 985-994.

Geliş Tarihi / Received Date: 11.04.2019

Kabul Tarihi / Accepted Date: 27.12.2019

\footnotetext{
${ }^{1}$ Bu çalş̧ma 22-25 Mart 2018 tarihinde Ankara'da düzenlenen Gastronomi Kongresi’nde sözlü olarak sunulmuştur.

2 Arş. Gör. - Gümüşhane Üniversitesi Turizm Fakültesi, s.sedakamber@gmail.com ORCID: 0000-0002-4245-0515

3 Öğr. Gör. - Gümüşhane Üniversitesi Turizm Fakültesi, sedattas61@gmail.com

ORCID: 0000-0003-3555-7530
} 


\section{Giriş}

Son yıllarda ekonomik anlamda ülkelere önemli katkılar sağlayan turizm sektörü, kültürel ve geleneksel değerlerin tanıtımında da etkin bir rol oynamaktadır (Orhan, 2010, s. 243). Coğrafi açıdan bir bölgeye/yöreye özgü özelliklerin ön plana çıkmasına ve bölgenin tanınırlığını arttırmaya yardımcı olan yöresel ürünlere talep hızla artmaktadır (Schneider ve Ceritoğlu, 2010, s. 30). İşte bu bağlamda Avrupa'da Fransa gibi ülkelerin şarap, peynir vb. bazı ürünlerde kullandıkları koruma uygulaması ilk olarak 1992 yllında Avrupa Birliği ülkelerinde, daha sonrada uluslararası alanda Coğrafi İşaret sistemi içerisinde şekillenmeye başlamıştır (Kan, Gülçubuk ve Küçükçongar, 2012, s. 93). Yöresel değerleri ekonomiye kazandıran, coğrafi işareti alan bölgenin tanıtımını yapan (Özkaya, Sünnetçioğlu ve Can, 2013, s. 17) ve daha da önemlisi sahip olunan bu değerlerin korunarak sonraki nesillere de aktarılmasına aracı olan coğrafi işaretler önemli bir sınaî mülkiyet hakkı olarak tanımlanmaktadır (Tanrıkulu, 2011, s. 181).

Bu çalıșma, Gümüşhane ilinin coğrafi işaretli ürünlerinden iki tanesi olan Gümüşhane Dut Pestili ile Gümüşhane Kömesi üretim ve satış faaliyetlerini gerçekleştiren işletmecilerin, coğrafi işaret tesciline ve tescil belgesi edinmeye yönelik bakış açılarının ortaya konması amacıyla gerçekleştirilmiştir. Literatürde Gümüşhane özelinde coğrafi işaretli ürünlere yönelik çalışmaların yetersiz olmasından dolayı bu çalışmanın literatüre ve sektöre katkısının olacağı düşünülmektedir.

\section{Literatür Taraması}

Bu bölümde araştırma kapsamı içerisinde yer alan coğrafi işaret kavramı, Gümüşhane Kömesi ve Gümüşhane Dut Pestili konuları ele alınmıştır.

\section{Coğrafi İşaret Kavramı}

Günümüzde teknolojinin gelişmesiyle birlikte üretim süreçleri çeşitlenmiştir. Gelişen teknolojiyle seri üretimlerin ve ürün çeşitliliğinin de artması, g1da güvenliği kontrollerini giderek zorlaşır bir hale getirmeye başlamıştır (Meral ve Şahin, 2013, s. 16). Sağlığını korumayı ve sağlıklı olmayı arzu eden tüketicilerin, doğal yöntemlerle üretilen ve güvenilirliğini uzun yillar boyunca kanıtlamış olan yerel ürünlere karşı duydukları tüketim talebi artmıştır (Doğan, 2015, s. 60). Yiyip içtikleri ürünler hakkında doğru bilgi edinmeyi isteyen tüketiciler, sertifikasyon sistemlerini önemsemeye başlamışlardır. Tükettikleri gıdaların içerikleri, üretim aşamaları, doğa ile ilişkileri günümüz tüketicileri için anlam taşımaktadır (Orhan, 2010, s. 245). Ürün etiketlerindeki son kullanma tarihi, saklanma ve pişirilme koşulları, ürün üretim yeri gibi konular tüketiciler açısından önemsenmeye başlamıştır (Şahin ve Meral, 2012, s. 89). Bu bakımdan; geleneksel üretimi teşvik etmesinin yanı sıra yerel yiyeceklerin ve içeceklerin özlerinin korumasını sağlayarak ürünün ait olduğu bölgeye veya yöreye turist çekmesine destek olan coğrafi işaretlerin önemi büyüktür (Mercan ve Üzülmez, 2014, s. 68). Konu ile ilgili tüketici eğilimlerinin fark edilmesiyle birlikte yöresel ve özgün olanı korumak adına yürürlüğe konulan ilk uygulama 1992 yılında öncelikle Avrupa Birliği ülkelerinde görülmüştür. Daha sonra ise coğrafi işaret sistemi içinde (Kan vd., 2012, s. 93) ürünün, üreticinin ve tüketicinin korunması adına ulusal ve uluslararası düzeyde gerekli adımlar atılmıştır (Gökoval, 2007, s. 144). Coğrafi işaretler sistemi ile ilgili gerçekleştirilen uluslararası anlaşmalar (Jain, 2009, s. 71-72);

- Sınai Mülkiyet Haklarının Korunmasına İlişkin Paris Sözleşmesi

- Ürünler üzerinde kullanılan sahte ya da aldatıcı Mahreç İşaretlerinin engellenmesine ilişkin Madrid Anlaşmas1

- Menşe Adlarının korunması ve uluslararası tesciline ilişkin Lizbon Anlaşması

- Ticaretle Bağlantılı Fikri Mülkiyet Hakları Anlaşması'na ilişkin TRIPS Anlaşması (Trade-Related Aspects of Intellectual Property Rigths).ile gerçekleştirilmiştir.

TRIPS sözleşmesi 22/1 maddesinde coğrafi işaret kavramı; 'üye bir ülkenin toprağından veya bu toprak üzerinde yer alan bir bölge veya yöreden kaynaklanan, belirgin bir niteliği, ünü veya diğer özellikleri itibariyle esas olarak bu coğrafi menşeye atfedilen ürünleri tanımlamak için kullanılan işaretlerdir' ifadeleriyle tanımlanmaktadır (The World Trade Organization, 2017; Rahmah, 2017, s. 91). Kültürel ve gastronomik değerler; şehirlerin, bölgelerin ve ülkelerin turizm pazarlamalarında avantajlı bir duruma geçmesine, ekonomik kazançlar elde etmesine ve yeni alanların gelişmesine kaynak sağlamıştır. Sahip olduğu coğrafi, iklimsel ve kültürel çeşitliliklerin etkisiyle gelişen zengin Türk Mutfağı, her bölgesinde barındırdığı farklı gastronomik değerlerle bu açıdan büyük önem bir taşımaktadır (Kamber Taş ve Taş, 2017, s. 1). Türkiye'nin sahip olduğu zengin yöresel ürün çeşitliliğinin korunabilmesi adına gerekli yasal düzenleme 27.06.1995 tarihinde yürürlüğe giren 555 sayılı Coğrafi İşaretlerin Korunması Hakkında Kanun 
Hükmünde Kararname ile gerçekleştirilmiştir (Toklu, Ustaahmetoğlu ve Öztürk Küçük, 2016, s. 146; Altuntaş ve Gülçubuk, 2014, s. 76). Türkiye'de coğrafi işaretlerin tescili ile ilgilenen kurum Türk Patent Enstitüsü'dür. Başvurular Türk Patent Enstitüsüne veya onun yetkili kıldığı makama yapilır (Kan vd., 2012, s. 97). Türk Patent Enstitüsü coğrafi işaret kavramını; belirgin bir niteliği, ünü ya da diğer özellikleri itibariyle kökenin bulunduğu bir yöre, alan, bölge ya da ülke ile özdeşleşmiş bir ürünü gösteren bir işaret olarak tanımlanmaktadır (TPE, 2017a). Türk Patent Enstitüsü’nce 09.02.2017 tarihi itibariyle 316 adet tescilli coğrafi işaret olup, başvurusu değerlendirme sürecinde olan 404 adet ürün bulunmaktadır (TPE, 2017b). Bir ürünün coğrafi işaret tescili alabilmesi için; tüketiciler arasında iyi bir üne sahip olmal, hammadde üretimi ve hazırlanma süreci belirlenmiş bir coğrafi alanda gerçekleştirilmeli, benzerlerinden farklı ayırt edici bir özelliği bulunmalı ve detaylı bir şekilde tanımlanmış özel bir üretim sürecinin ürünü olmalidır (Oraman, 2015, s. 78).

Yenipınar vd. (2014, s. 14) coğrafi işaret tescilinin başlıca amaçlarını şu şekilde ifade etmiştir;

- Ürünün korunması: Coğrafi işaretli ürünün kalitesinin korunarak ve garanti edilen özellikleriyle üretiminin sağlanması.

- Üreticinin korunması: Yöre veya yöre dışında belirtilen kriterlerde coğrafi işaretli ürün üretimi yapanların tescilin sağladığı korumadan öncelikli olarak yararlanmalarının sağlanması.

- Tüketicinin korunması: Coğrafi işaret tescil ambleminin, orijinalini yansıtmayan ürünler üzerinde kullanılmasının önüne geçilmesi.

- Kültürün korunması: Ülkenin milli ve kültürel değerlerinin korunmasının sağlanmasıdır.

Coğrafi işaret tescili, tüketicide tescilli ürüne karşı prestij ve güven sağlayan bunun yanı sıra üreticilerin piyasadaki rakiplerinden farklılaşmasına aracı olan bir mekanizma olarak işlev görmektedir (Bagade ve Metha, 2014, s. 1226). Coğrafi İşaretleme Sisteminin temel fonksiyonları şu şekilde ifade edilmektedir;

- Köken Belirtme Fonksiyonu: Coğrafi işaretler ürünlerin kökeni veya hangi bölgeye ait olduğunu gösteren semboller olarak görev yapar.

- Kalite Fonksiyonu: belirli ürünlerin niteliklerini tanımlar ve tüketiciye belirtilen kriterler çerçevesinde beklentilerini karşılama garantisi sunar.

- Yatırım veya Reklam Fonksiyonu: yanlış beyan veya herhangi bir suistimal açık durum olmayacağı için, ürün coğrafi işaret tesciliyle bağlı bulunduğu bölgenin ve ürünün tanıtımının yapılmasında bir araç olarak görev alır. Bölgeye de ekonomik olarak katma değer sağlar.

- Kültür Koruma Fonksiyonları: Ürünlerin geleneksel üretim yöntemlerini, tüketim alıskanlıklarını ve kültürel kimliğini korur (Bagade ve Metha, 2014, s. 1228; Rovamo, 2006, s. 7).

Coğrafi işaretler mahreç işareti ve menşe adı olarak ikiye ayrıllır. Bir ürünün üretiminden bitimine kadar tüm işlemler ilgili bölgede gerçekleşiyorsa buna menşe işareti, bu aşamaların en az biri ilgili bölgede gerçekleşiyorsa mahreç işareti verilmektedir (Özkaya vd., 2013, s. 17; Tanrıkulu, 2011, s. 174). Samsun Simidi, Çarşıbaşı Keşanı, Gümüşhane Kömesi, Akçaabat Köftesi, Hamsiköy Sütlacı mahreç adı ile korunan ürünlere örnek teşkil ederken; Malatya Kayısısı, Isparta Gülü, Niksar Cevizi, Devrek Bastonu, Kars Kaşarı, Afyon Mermeri de menşe işareti ile korunan ürünlere örnek olarak sıralanabilir.

\section{Gümüşhane Kömesi ve Gümüşhane Dut Pestili}

Tarihte pestil ve kömenin yapımının başladığı yıllar net bir şekilde bilinmemekle birlikte uzun yıllar öncesine dayandığı tahmin edilmektedir. Yapılan kaynak araştırmalarında, pestil ve kömenin Anadolu’ya ait bir değer olduğuna ve Osmanlı döneminde de yapıldığına dair bilgilere rastlanılmaktadır. Eskiden insanların; bölgede çokça bulunan dut ağaçlarından elde ettikleri dutların şırasını çıkararak, un ile pişirip temiz bezlere serildikten sonra güneşte kurutup teneke veya küp içerisine konularak, nemsiz bir ortamda kış aylarında tüketilmek üzere muhafaza ettikleri, yaz aylarından kışa hazırlıklar yaptıkları bilinmektedir (Kalkışım ve Özdemir, 2012, s. 11).

Gümüşhane bölgesinde uzun ylllar boyunca ev ölçeği bazında varlık gösteren dut pestili ve kömesi bölgenin önemli ve geleneksel gastronomik ürünleri olarak ifade edilmektedir. 70'li yılarların ortalarında küçük bir imalathane, 90’lı yılların sonlarında ise fabrika ölçeğinde üretimine başlanan köme ve dut pestili, endüstriyel ve ticari açıdan ilk kez Büyükbayraktar ailesi tarafından yöresel bir kazanç kaynağına 
dönüştürülmüştür (Akyüz ve Kara, 2016, s. 137). Böylelikle mevsimsel üretim dönemi geri birakılıp, 12 ay boyunca sürdürülebilir üretim dönemi başlamıştır.

\section{a) Gümüşhane Kömesi}

Ceviz parçalarının ipe dizilerek belli bir kalınlığa ulaşıncaya kadar pestilin de hammaddesi olan herleye 4-5 kez daldırılıp kurutulması yöntemiyle elde edilen ürün, Gümüşhane Kömesi olarak adlandırılmaktadır (Gümüşhane Valiliği, 2010, s. 41). Bu coğrafi işaretli ürün, 27.07.2003 tarih ve 25181 say1lı resmi gazetede ilan edilmiş ve 555 sayılı Coğrafi İşaretlerin Korunması Hakkındaki Kanun Hükmündeki Kararname'nin 12’nci maddesi gereğince 23.01.2004 tarihinden itibaren korunmak üzere mahreç işareti ile tescil edilmiştir. Coğrafi işaret tescil belgesine göre Gümüşhane Kömesi'nin ayırt edici özellikleri şöyle tanımlanmaktadır; "Gümüşhane kömesi diğer bölgelerde üretilen cevizli sucuğa benzemekle birlikte önemli farkl1lıklar göstermektedir. Gümüşhane Kömesi yapılırken iplere dizilmiş iç cevizin batırıldığ1 karışımın içeriği oldukça farklıdır. Bu içerikte bal, süt, dut, şeker ve un bulunmaktadır. 100 kg Gümüşhane Kömesi elde etmek için en az 33kg. ceviz, en az $14 \mathrm{~kg}$ bal, en az $10 \mathrm{~kg}$ süt kullanılmaktadır. Süt ve dut bu bölgede elde edilmektedir. Gümüşhane Kömesi’nin yapımında ve kalitesinde köme ustalarının becerileri ve yörenin zengin flora yapısından elde edilen dut önemli bir etkendir" (Türk Patent ve Marka Kurumu, 2004a).

\section{b) Gümüşhane Dut Pestili}

Dut, bal, süt ve un karışımının herle haline getirilip içerisine findık veya ceviz katılarak bezlere serilip kuruduktan sonra elde edilen besin değeri yüksek olan gıda maddesi Gümüşhane Dut Pestili olarak tanımlanmaktadır (Gümüşhane Valiliği, 2010, s. 25). Bu coğrafi işaretli ürün, 27.07.2003 tarih ve 25181 sayılı resmi gazetede ilan edilmiş ve 555 sayılı Coğrafi İşaretlerin Korunması Hakkındaki Kanun Hükmündeki Kararname'nin 12'nci maddesi gereğince 23.01.2004 tarihinden itibaren mahreç işareti ile korunmak üzere tescil edilmiştir. Coğrafi işaret tescil belgesine göre Gümüşhane Dut Pestili'nin ayırt edici özellikleri şöyle tanımlanmaktadır; 'Gümüşhane pestili diğer bölgelerde üretilen pestillerden daha parlak ve yumuşak bir yapıdadır. Diğer bölgelerde üretilen pestillerden farklı olarak içeriğine bal ve süt katılmakta ayrıca diğer bölgelerde üretilen çeşnili pestillerde kullanılan iç ceviz ve iç findık çok daha fazla miktarlarda katılmaktadır.100 kg Gümüşhane Pestili elde etmek için en az 20kg bal, en az $15 \mathrm{~kg}$ süt, en az $20 \mathrm{~kg}$ iç ceviz veya iç findık kullanılmaktadır. Süt ve dut bu bölgede elde edilmektedir. Gümüşhane Pestili’nin yapımında ve kalitesinde pestil ustalarının becerileri ve yörenin zengin flora yapısından elde edilen dut önemli bir etkendir.' (Türk Patent ve Marka Kurumu, 2004b).

\section{Yöntem}

Araştırma verileri kalitatif bir araştırma tekniği olan, yarı yapılandırılmış mülakat yöntemi kullanılarak elde edilmiştir. Bu teknikte araştırmac1, önceden sormay1 planladığ1 soruları içeren görüşme formunu hazırlar (Türnüklü, 2000, s. 47). Tam yapılandırılmış mülakatın aksine yapılan görüşmenin gidişatına bağlı olarak sorularda değişiklikler yaparak ek sorular sorabilir. Bu sayede görüşülen kişinin bilgilerini aktarmasında ortaya çıkabilecek olası sınırlamaların önüne geçilerek, ilgili konuda daha detaylı bilgilere ulaşılabilmektedir (Merriam, 2013, s. 87-88). Yarı yapılandırılmış görüşme tekniğinin araştırmacıya sunduğu en önemli kolaylık sistematik ve karşılaştırılabilir bilgi sunmasıdır (Yıldırım ve Şimsek, 1999, s. 283).

\section{Evren - Örneklem}

Çalışmanın amacından hareketle; 15-25 Ocak 2018 tarihleri arasında Gümüşhane ilinde faaliyet gösteren, Gümüşhane Kömesi ve Gümüşhane Dut Pestili üretimi yapan işletme sahipleri ile görüşmeler gerçekleştirilmiştir. Nitel araştırmalarda araştırmacının verilerin doyuma ulaştığını bir diğer ifadeyle devamlı benzer şeylerin anlatıldığını hissetmeye başladı̆̆ı zaman yeterli katılımın sağlandığına karar verilebileceği (Merriam, 2013, s. 207) göz önünde bulundurularak, araştırma dâhilinde 8 işletme sahibi ile gerçekleştirilen görüşmeler yeterli görülmüştür.

\section{Veri Toplama Araçları}

Araştırmada, veri toplama aracı olarak yarı yapılandırılmış görüşme formu kullanılmıştır. Görüşme soruları hazırlanmadan önce, araştırma konusu ile ilgili literatür taraması yapılmış ve görüşme formunda yer alması düşünülen sorular hazırlanmıştır. Görüşme formunda; coğrafi işaret kavramı, coğrafi işaret tescili, Gümüşhane Kömesi ve Dut Pestili'nin hazırlanış şekli, muhafaza koşulları, denetimi konularını ele alan ve bu konulara ait alt sorular yer almaktadir. 


\section{Verilerin Analizi}

Araştırmadaki tüm görüşmeler veri kaybı yaşanmaması amacıyla ses kaydı alınarak gerçekleştirilmiştir. Yapılan görüşmeler 30 ile 55 dakikalık süreler arasında gerçekleşmiştir. Yapılan sekiz görüşme toplam 4 saat 22 dakika sürmüştür. Elde edilen kayıtlar analiz edilmek üzere araştırmacı tarafindan deşifre edilip yazıya dökülmüştür. Görüşmelerden elde edilen veriler ve ilgili doküman incelemeleri betimsel olarak analiz edilmiştir. Görüşülen kişilere yapılan atıflarda, katılımcıların talepleri doğrultusunda isim kullanmamak adına kodlamalardan yararlanılmıştır. Bu bağlamda görüşülen işletmeler ve katılımcıları $\mathrm{A}, \mathrm{B}$, C, D, E, F, G ve H harfleri ile kodlanmıştır.

\section{Bulgular}

Makalenin Yapılan görüşmelerde B işletmesi sahibi dışındaki bütün katılımcıların coğrafi işaret kavramını duydukları; Gümüşhane Kömesi ve Gümüşhane Dut Pestili’nin coğrafi işaret tescili ile koruma altına alındığ1 konusunda bilgi sahibi oldukları tespit edilmiştir. Katılımcılar coğrafi işaretleme sistemi ile ilgili bilgilere Gümüşhane Ticaret ve Sanayi Odası tarafindan düzenlenen toplantılarda dönem dönem yer verildiğini ifade etmişlerdir. $\mathrm{B}$ işletmesi sahibi dışındaki tüm katıllımcıların coğrafi işaretleme sistemi hakkında bilgi sahibi olmalarına rağmen, A işletmesi sahibi dışındaki tüm katıllımcılar işletmelerinde ilgili ürünlerin satışı ve tanıtımı için coğrafi işaret tescil belgesini/logosunu kullanmadıklarını ifade etmişlerdir. Görüşmelerden edinilen bu bilgi, ilgili ürünler adına başvuru sahipliği yapan Gümüşhane İl Özel İdare Müdürlügü̈nden alınan bilgi ile desteklenmiştir. A işletmesi dışındaki il sınırları içerisinde faaliyet gösteren hiçbir işletmenin coğrafi işaret tescil belgesini/logosunu kullanmak adına Gümüşhane İl Özel İdare Müdürlüğüne başvuruda bulunmadığı tespit edilmiştir.

\section{Coğrafi İşaret Tesciline Bakış Açısı}

A işletmesi il sınırları içerisinde coğrafi işareti ürünlerinde kullanan tek işletme olarak, coğrafi işaret tesciline bakış açısını şu sözlerle ifade etmiştir; "Biz 3 sene önce başladık ürünlerimizde coğrafi işareti kullanmaya. Gross marketlere ürün hazırlarken coğrafi işaretli ürünlerimizi amblemsiz diye kabul etmediler. Çünkü bize şunu söylediler müşteriler işletmelerine geldiklerinde o amblemleri görerek coğrafi işaretli ürünler tercih edebileceklerini bize belirttiler. Bizde ürünlerimizi doğal olarak ürettiğimizi herkese göstermek, kapılarımızı herkese her denetime açarak gelsinler görsünler diyerek coğrafi işaretli ürün üretmeye karar verdik. Zaten işletmeme güveniyorum her şeyimiz ortada herkes gelsin görsün denetlensin. Fakat bizden başka kimse kullanmıyor bu işareti burada. Kullanırlarsa girecekleri denetimde gereken şartları sağlayamayacakları için, maliyetleri yüksek olduğu için belirlenen kalite standartları sağlayamayacakları için kullanmıyorlar. Uzun vadede varlık göstermek ya da daha büyük pazarlara hitap etmek gibi bir amaçlarının olmadığını düşünüyorum. Bu memleket adına bir adım atalım katkıda bulunalım buranın gelişmesine bir katkı sağlayalım gibi bir düşüncesi yok. Ulusal ya da Uluslararası bir satış yapma ya da tanıtım yapma, katkı sağlamak gibi amaçlarının, kaygılarının olmadığını düşünüyorum”.

B işletmesi coğrafi işaret sistemi ile ilgili bilgi sahibi olmadığını belirttiği için öncelikle kendisine konu ile ilgili gerekli bilgiler verilmiş daha sonra bu sistemi nasıl değerlendirdikleri sorulmuştur. B işletmesi "Söylediklerinize göre aslında bu iyi bir şey. Adil rekabet olur. Belki satışlara da etki eder. Ama yine de bilemiyorum, emin değilim" diyerek tescil belgesini edinmeye karşı olan görüşlerini ifade etmiştir.

C, D, G ve E işletmeleri sahipleri tescil belgesini/logosunu kullanmayı düşünmediklerini belirtirken $\mathrm{D}$ işletmesi "Bence belgenin bize hiçbir faydası olmayacak. Benim satışlarımı da artıırmaz, güven de vermez. Beni zaten bilen, güvenen kişi geliyor bana" şeklinde ifadeler kullanarak coğrafi işaret tescil belgesini işletmesi için gerekli görmediğini ifade etmiştir.

$\mathrm{E}$ işletmesi ise tescil belgesini ürünlerinde kullanmayı tercih etmemesinin sebebini işletmesinin yeterince kurumsallaşmaması gerekçesine bağlayarak "bu gibi işaretleri kullanmak için işletmemizin biraz daha kurumsallaşması gerektiğini düşünüyorum öncelikli olarak. Daha sonra coğrafi işaret belgesini alma durumumuz ortaya çıkabilir. Kendimizi tam olarak kurumsallaşmış göremediğimiz için almak istemedik ve düşünmüyoruz daha doğrusu" diyerek kısa vadede coğrafi işaret tescilini kullanmayı düşünmediklerini belirtmiştir.

$\mathrm{H}$ ve $\mathrm{F}$ işletmeleri sahipleri ise tescil belgesini işletmelerinde kullanmadıklarını ancak kullanmayı düşünebileceklerini belirtmişlerdir. $\mathrm{H}$ işlemesi sahibi "tescil belgesine olumsuz bakmıyoruz aslında. Baktığınız zaman çok da geçerli bir sebebimiz yok kullanmıyor oluşumuzun. Aslında sertifika sistemine 
geçmemizin tabi ki faydası vardır. Bu da bir güven verir. Ben mesela aldığım ürünlerden nasıl içerik analizi istiyorsam müşteri de tükettiği üründe elbette sertifikalı ürün almak ister. Ama bir yandan da Gümüşhane'deki tüketicinin coğrafi işareti önemseyeceğini düşünmüyorum. Derseniz ki peki dışarıdaki tüketici? Bakın işte o önemser.” diyerek konu ile ilgili bakış açısını belirtmiştir.

\section{Gümüşhane Kömesi ve Dut Pestili’nin Hazırlanış Şekli}

A işletmesi Gümüşhane Kömesi ve Dut Pestili'nin ilk yapım aşamalarıyla ilgili tecrübelerini şu şekilde ifade ediyor; “Kara kazan vardı 1974'lü yıllarda. Yani bu ürünü sektör haline getiren ilk aileyiz Gümüşhane'de. Gümüşhane'de böyle bir şey yoktu. Bir tek yazın yapılırdı evlerde. Herkesin evinin önünde dut ağacı vardı. Herkes ondan dutlarını silkeler pekmezini yapardı. Kışlık yiyecek olarak saklar sobalarda 1sıt1lırd1. Sonra biz bunu nasıl yaparız da bu ürünü nasıl yerden kaldırırız diye düşündük. Toprak bahçelerde bezlerin üzeri seriliyordu kuruyunca da öyle tüketiliyordu. Sonra kara kazan değil de bu pişirmeyi daha iyi nasıl hijyenik hale getiririz diye düşündük. Bu sefer yağlı cidarlı kazanlı bulduk. Yani tamamen deneme yanılma yoluyla kendi argemizi kendimiz yaptık. İşin kötüsü bu ürün o yılarda geniş çaplı bilinmeyen de bir ürün. Hani makarna fabrikası açmıyorsun ki gidesin makine getirip dizayn edesin. Sonra düşündük Biz bunu yerden ayağ1 nasıl kaldırabiliriz. Köyceğiz'de gittiğimiz zaman sinek telleri var ya sineklikler onları böyle kasalara dizdik havaya kaldırdık kurduk pestilleri üzerine serdik. Bir ay sonra bir baktık ki hepsi kuruyup düştü koptu. Sonra anladık ki bu işte bu kadar güneş olmaz. Sonra krom tezgâhları bulduk işte. Sürekli biz bu işi 12 aya nasıl yayabiliriz diye düşündük. Annem de bunu kuru duttan da yapabileceğimizi söyledi. Kuru dutu pişirin alın dedi. Bu sefer kendimize sıcak odalar oluşturmaya çalışıp, düplor ederek kurutmaya başladık dutları. Kendi dehidratörünüzü kendimiz yapmaya çalıştık. O zamanlar işte hiçbir şey yoktu, imkânsızlık vardı”. Katılımcıların her biri ürünlerin yapımda kullanılan malzemeleri köme için bal, süt, dut, şeker, ceviz olarak; pestil için ise dut, bal, ceviz veya findık, un, süt olarak ifade etmiştir.

A, E ve $H$ işletmeleri sahipleri Gümüşhane Kömesi ve Dut Pestili'nin yıllar önceki asıl hazırlanış şeklinde balın kullanılmadığını bu yüzden ürünlerin çok sert olduğunu ancak sektör haline gelmeye başlanmasıyla daha yumuşak olması ve kalması adına bal malzemesinin kullanılmaya başladığı bilgisini vermişlerdir.

F işletmesi sahibi ise ürün yapımında tescil belgesine göre kullanılması gereken tüm malzemeleri sayarak, kendilerinin ürünlerinde glikoz şurubu da kullandıklarını açıkça belirtmiştir. Hatta pek çok işletmenin de kendileri gibi beyan etmese bile ürünlerine glikoz şurubu eklediklerini öne sürmüştür. B ve $\mathrm{E}$ işletmesi sahipleri de kendi ürünlerinde kullandıklarını söylemeseler de şöyle ifadelerde bulunmuşlardır; B işletmesi "Glikoz şurubu gida sektöründe zaten kullanılıyor. Ürünlerin raf ömrü uzasın diye kullanabilirler. Miktar az ise sorun olmaz diye düşünüyorum. Ben kullanmiyorum”. E işletmesi 'Glikoz şurubunu Tarım Bakanlığı'nın belli bir oranda kullanılabileceği ile ilgili bir bilgi var. Şöyle ki şu an tükettiğimiz bütün gıdaların içerisinde olan bir maddedir. Bisküviden çikolataya, dondurmaya kadar her şeyin içerisinde var. Pestil ve köme de de olabilir, kullanılabilir. Ama bir düzeyde \% 10, \% 5 daha uygun. Bakanlığın göstermiş olduğu miktarda kullanabilir. Ben tercih etmiyorum, kullanmıyoruz. Kullanan arkadaşlar içinde insan sağlığına zarar vermeyecek şekilde standartlarda kullanılmasında sakınca olduğunu düşünmüyorum'. Piyasada ürünlerde glikoz şurubu kullanımın yanı sıra maliyeti düşürmek için düşük kaliteli mamullerin de üretimde işletmelerce kullanılabildiğine dikkat çeken A işletmesi sahibi “ evet coğrafi işaret tescil belgesinde ürünün nasıl hazırlanması gerektiği yazıyor fakat her şey ne yazık ki yazıldığı gibi olmuyor. Bu fiyatlardan da belli oluyor. Gümüşhane'deki köme ve pestil satış fiyatları kilosu 20 liradan başlayıp firmasına göre 40 liraya kadar çıkıyor. Peki herkes aynı kalitede mal kullansa mümkün mü bu kadar fark? Hemen bir örnek vereyim. Benim fabrikaya giren her şey denetimden geçiyor. Ben çifte kavrulmuş bir birinci kalite bir numaralı findık alıyorum ve çekilmiş fındık asla almıyorum. Ben kendi fabrikam da çekiyorum, çünkü malzemeyi görmem lazım. Bu ürünün kilosu 35 lira. Ama sen çekilmiş fındık alırsan, fındık iyi midir, alfa toksin üretmiş midir diye düşünmez alırsan kilosu 20 lira. Şimdi ne yapıyorlar ambarda deposunda ne kadar findık varsa sıkıntılı malzeme varsa çekiyor ondan sonra burada pazara giriyor. İşte şunu ortaya koyuyor; sen ürünü şekerle değil de glikozla yaparsan, findığı bütün değil çekilmiş alırsan, sütü de suyla karıştırırsan bu işler sağliklı olmaz" ifadelerinde bulunmuştur. Edinilen bilgilere ek olarak katılımcıların her biri köme ve pestilin hazırlanış aşamalarını tescil belgelerindeki bilgileri doğrular şeklide yapmiştır. 


\section{Muhafaza Koşulları}

Katıllımcların her biri ürünlerin serin ve kuru bir ortamda muhafaza edilmesi gerektiğini söylemişlerdir. Ancak tüketim tarihleri konusunda farklı ifadeler kullanmışlardır.

A işletmesi sahibi “Aslında bir yll tüketim süresi var ama biz 6 ay vuruyoruz ürünlerimizin paketlerine üzerine. Biz içerisinde koruyucu koyarak raf ömrünü uzatmak istemiyoruz. Dolayısiyla 6 ay olarak etiketliyoruz" demiştir.

F ve $B$ işletmeleri sahipleri ürünlerin 'serin havada 3 ay sıcak havalarda 1 ay içinde' tüketilmesi gerektiğini ifade ederken D işletmesi 'oda sıcaklı̆̆nda 1 ay 10 derece sicaklıkta 3 ay içinde' tüketilmesi gerektiğini söylemiştir.

$C$, E ve $G$ işletmeleri sahipleri 'ortalama raf ömrü 6 aydır' derken $H$ işletmesi sahibi 'Bizim tavsiyemiz şudur sonuçta bu gıda maddesidir. Yani bizim ülkemize göre pestilin hava şartlanna göre Gümüşhane'de nem oranı düşüktür ama Trabzon'daki nem oranı daha yüksektir. Oraya getirince bozulabiliyor dolayısıyla iklimine göre saklanma şartları. Biz müşterimize diyoruz ki bizden aldığınız ürünleri taze tüketim 1 ay 2 ay içerisinde tüketmeniz almıs olduğunuz ürünler için daha iyi olacaktır" ifadelerini kullanmıştır.

\section{İşletmelerin İlgili Kurumlarca Denetimi}

İ sınırları içerisinde yalnızca A işletmesi ilgili coğrafi işareti kullandığı için, ürünlerin coğrafi işaret tescil belgesinde belirtilen "Gümüşhane İl Özel İdare Müdürlüğü koordinatörlüğünde Tarım İl Müdürlüğü, Sanayi Müdürlüğü ve İl Sağllk Müdürlügünce oluşturulacak en az 3 kişilik konusunda uzman komisyonca yılda en az iki kez, şikayet halinde ise her zaman" olmak üzere denetimlere tabii tutulduğunu söylemiştir. Diğer katılımcı işletme sahiplerine gıda üretimi ve satışı yapan işletmeler olarak ilgili kurumlarca ne sıklıkta denetim gördükleri sorulmuş ve birbirinden farklı cevaplar alınmıştır. Verilen cevaplarda denetimlerin en sık 15 günde bir, en uzun arayla ise yılda bir iki kez gelindiği söylenmiştir.

\section{Tartışma, Sonuç ve Öneriler}

Makalenin Coğrafi işaretli ürün üretimi gerçekleştiren işletmecilerin coğrafi işaret tesciline ve tescil belgesi edinmeye yönelik bakış açlarının incelenmesi amacıyla, Gümüşhane il sınırları içinde Gümüşhane Kömesi ve Gümüşhane Dut Pestili üretim yapan işletme sahipleriyle gerçekleştirilen görüşmeler sonucunda; bir tane işletme dışında coğrafi işaret tescilini ürünlerinde kullanan işletme bulunamamıştır. $\mathrm{Bu}$ bulgu araştırmanın en çarpıcı sonuçlarından birisidir. Mevcut durum alınan coğrafi işaret tescil belgesinin ürünün, üreticinin ve tüketicinin korunması adına işlevini yerine getirememesine sebep olmaktadır. Uygulamaya konulmamış hiçbir belge amacına hizmet edememektedir. En kısa sürede işletme sahipleri ile ilgili kurumlar iletişime geçmeli, işletmeler coğrafi işaret tescilini kullanmaya teşvik edilmelidir. Hem işletmecilerin hem de bu ürünü tüketen yerel halkın bilinçlenmesi için bilgilendirme çalısmaları yapilmalıdır.

Coğrafi işaret tescili, işletmeler tarafindan benimsenerek kullanılmadı̆̆ için coğrafi işaretli ürünlerin (Gümüşhane Kömesi ve Gümüşhane Dut Pestili) üretiminde glikoz şurubu, su ile karıştırılmış süt, alfa toksinli çekilmiş findık gibi ürünün aslına uygun olmayan mamullerin kullanıldığı ifade edilmiştir. $\mathrm{Bu}$ durum eğer gerekli önlemler alınmaz ise gerek yöresel gastronomik ürünlere yönelen ve önemseyen tüketiciye gerekse sağlkklı ve aslına uygun olarak ürün üretmeyi arzu eden üreticilere olumsuz olarak yansıyacaktır. Tüketicilerin coğrafi işaretli ürün algıları ölçmeye yönelik yapılan çalışmalar da (Bonnet ve Simioni, 2001; Ertan, 2010; Ittersum ve Janssen, 2007) tüketicilerin bölgesel etiket taşıyan ürünlere tüketiciye güven duygusu vermesinden dolayı, artı değer biçerek emsallerinden daha fazla ücret ödemeye eğimli oldukları görülmektedir. Böylece coğrafi işaretler aracıllğ̣yla hem bölgesel ekonomilerin canlanmasına potansiyel sağlanmış olacak, hem de kırsal kalkınmaya katma değer sağlanacaktır (Ertan, 2010; Mercan ve Üzülmez, 2014; Orhan, 2010).

İşletmelerin coğrafi işaret tescilini kullanmıyor olmalarına bağlı olarak denetimlerin yeterli ve yöresel ürünü korumaya yönelik olarak gerçekleştirilmediği görülmüsstür. Coğrafi işaretli ürünlerde yaşanan denetim sorunu Doğdubay ve Sünnetçioğlu (2015) ile Taşdan, Albayrak ve Albayrak'ın (2014) yapmıs oldukları çalışmalar sonucuyla benzerlik göstermektedir. Bu durum coğrafi işaretli yöresel ürünün yapilışında uygun olmayan mamullerin kullanımına zemin sunmaktadır. Aslına uygun ürünlerin hazırlanarak, sağlıklı ve güvenilir ürün tüketme arzusu duyan tüketicileri ve işletmeleri korumak adına 
işletmeler tescil belgesini kullanmaya yönlendirilmeli böylece denetimler düzenli olarak gerçekleştirilmelidir.

Dört adet tescili coğrafi ürüne sahip olan Gümüşhane ilinin tanıtımında tescilli ürünler son derece önemli bir rol oynamaktadır. Bu nedenle tescili alınan ürünlere yönelik denetimlerin de sürekli yapılmasının gerekmektedir. Bu denetimler sayesinde ürünlerin kaliteli bir şekilde üretilmesine ve sürdürülebilirliğe katk1 sağlayacaktır.

\section{Etik Beyan}

“İşletme Yöneticilerinin Coğrafi İşaret Tesciline Yönelik Bakış Açıları: Gümüşhane İli Örneği” başlıklı çalışmanın yazım sürecinde bilimsel, etik ve alıntı kurallarına uyulmuş; toplanan veriler üzerinde herhangi bir tahrifat yapılmamış ve bu çalışma herhangi başka bir akademik yayın ortamına değerlendirme için gönderilmemiştir.

\section{Kaynakça}

Akyüz, A. M. ve Kara, Ö. (2016). Gümüşhane örnekleminde pestil ve köme markalarının algısal konumlarının çok boyutlu ölçekleme analizi ile belirlenmesi. Gümüshane Üniversitesi Sosyal Bilimler Enstitïsï Elektronik. Dergisi, 7(16), 133-157.

Altuntaş A. ve Gülçubuk B. (2014). Yerel kalkınmada yaygınlaşan bir araç olarak geleneksel gıdalar ve geleneksel gıda mevzuatının yayginlaştırlabilirliği. Gažiosmanpaşa Üniversitesi Ziraat Fakïltesi Dergisi, 31(3), 73-81.

Bagade S. B and Metha, D. B. (2014). Geographical indications in India: Hitherto and challenges, Research Journal of Pharmaceutical, Biological and Chemical Sciences, 5(2), 1225-1239.

Bonnet, C. ve Simioni, M. (2001). Assessing consumer response to protected designation of origin labelling: A mixed multinomial logit approach, European Review of Agricultural Economics, 28(4), 433-449.

Doğan, B. (2015). Coğrafi işaret korumasının gelişmekte olan ülkeler için önemi, NWSA-Social Sciences, E-Journal of New World Science Academy, 10(2), 58-75.

Doğdubay, M. ve Sünnetçioğlu, A. (2014). Gastronomik kimliğin korunmasında coğrafi işaretlemenin rolü: İnegöl Köftesi örneği. Eko-Gastronomi Dergisi, 1(2), 47-59.

Ertan, A. (2010). Prestijli tarım ürünlerinin pazarlanmasında kalite ve coğrafi işaretler kavramlarının tutundurulması ve bu bağlamda tarım satış kooperatiflerinin önemi, Süleyman Demirel Üniversitesi Sosyal Bilimler Dergisi, 2(12).157170.

Gümüşhane Valiliği. (2010). Gümüşhane dut pestili ve kömesi, Gümüşhane Valiliği Yayınları.

Gökovalı, U. (2007). Coğrafi işaretler ve ekonomik etkileri Türkiye örneği. İktisadi ve İdari Bilimler Dergisi, 21(2), 141 160.

Janssen S. and Van Ittersum, M. K.. (2007). Assessing farm innovations and responses to policies: A review of bioeconomic farm models, Agricultural Systems, 94(3), 622-636.

Jain, S. (2009). Effects of the extension of geographical indications: A South Asian perspective, Asia-Pacific Development Journal, 16(2), 65-86.

Kalkışım, Ö. ve Özdemir, M. (2012). Pestil ve köme teknolojisi, (1.Baskı). Ankara: Gümüşhane Üniversitesi Yayınları.

Kan, M., Gülçubuk, B. ve Küçükçongar, M. (2012). Coğrafi işaretlerin kırsal turizmde kullanılma olanakları, KMÜ Sosyal ve Ekonomik, Arastrmalar Dergisi, 14(22), 93-101.

Kamber Taş, S. ve Taş, S.(2017). Doğu Karadeniz bölgesi gastronomik unsurlarının gastronomi turizmi açısından değerlendirilmesi, Uluslararası Turizm Sempozyumu, 23-24 Ekim, Trabzon.

Meral, Y. ve Şahin, A. (2013). Tüketicilerin coğrafi işaretli ürün algısi: Gemlik Zeytini örneği. Kabramanmaraş Sütşü İmam Üniversitesi Doğa Bilimleri Dergisi, 16(4), 16-24.

Mercan, Ş.O. ve Üzülmez, M. (2014). Coğrafi işaretlerin bölgesel turizm gelişimindeki önemi: Çanakkale ili örneği, Dokuz. Eylül Üniversitesi İktisadi ve İdari Bilimler Fakëlltesi Dergisi, 29(2), 67-94.

Merriam, S. B. (2013). Nitel arasstırma: desen ve uygulama için bir rebber. (Çev: S. Turan). Ankara:Nobel Yayınları.

Oraman, Y. (2015). Türkiye'de coğrafi işaretli ürünler, Balkan ve Yaken Doğu Sosyal Bilimler Dergisi, 1(1), 76-85.

Orhan, A. (2010). Yerel değerlerin turizm üzerine dönüş̧ürülmesinde coğrafi işaretlerin kullanımı: İzmit Pişmaniyesi örneği, Anatolia Turizm Araştrmalar Dergisi, 21(2), 243-254.

Özkaya, F., Sünnetçioğlu, S. ve Can, A. (2013). Sürdürülebilir gastronomi turizmi hareketliliğinde coğrafi işaretlemenin önemi, Journal of Tourism and Gastronomy Studies, 1(1), 13-30.

Rahmah, M. (2017). The protection of agricultural products under geographical indications:An alternative tool for agricultural devolopment Indenesia, Journal of Intellectual Property Right, 22(2), 90-103.

Rovamo, O. (2006). Monopolising names? The protection of geographical indications in the european community, Master's Thesis, Helsinki University.

Schneider, G. K. ve Ceritoğlu, A. B. (2010). Yöresel ürün imajının tüketici satın alma davranışı ve yüksek fiyat ödeme eğilimi üzerindeki etkisi-İstanbul ilinde bir uygulama. Pazarlama ve Pazarlama Arasttrmalar Dergisi, 3(6), 29-52.

Şahin, A. ve Meral, Y. (2012). Türkiye'de coğrafi işaretleme ve yöresel ürünler, Türk Bilimsel Derlemeler Dergisi, 5(2), 8892. 
Tanrıkulu, M. (2011). Türkiye'de coğrafi işaretlerin tespiti ve tescil edilmesinin önemi, Uluslararası Sosyal Bilimler Eğitimi Dergisi, 1(2), 173-184.

Taşdan, K., Albayrak, M. ve Albayrak, K. (2014). Coğrafi işaret tescilli geleneksel ürünlerde izlenebilirlik: Ankara ili örneği, XI. Ulusal Tarm Ekonomisi Kongresi, 1292-1300.

Toklu, İ.T., Ustaahmetoğlu, E. ve Öztürk Küçük, H. (2016). Tüketicilerin coğrafi işaretli ürün alg1sı ve daha fazla fiyat ödeme isteği: Yapısal eşitlik modellemesi yaklaşımı, Yönetim ve Ekonomi, 23(1), 146-161.

The World Trade Organization (2018). Section3: Geographical Indications. https://www.wto.org/english/docs_e/legal_e/27-trips_04b_e.htm (Erişim Tarihi, 03.03.2018)

Türk Patent ve Marka Kurumu, (2004a). Gümüşhane Kömesi Coğrafi İşaret Tescil Belgesi. https:/ /www.ci.gov.tr/Files/GeographicalSigns/62.pdf (Erişim Tarihi, 12.02.2018)

Türk Patent ve Marka Kurumu, (2004b). Gümüşhane Dut Pestili Coğrafi İșaret Tescil Belgesi. https://www.ci.gov.tr/Files/GeographicalSigns/63.pdf (Erişim Tarihi, 22.01.2018)

Türk Patent ve Marka Kurumu, (2017a). Coğrafi İşaret. http://www.turkpatent.gov.tr/TURKPATENT/resources/temp/6B3F914C-E72C-437C-8A30F50C51DE0A23.pdf (Erişim Tarihi, 23.01.2018)

Türk Patent ve Marka Kurumu, (2017b). Başvuru Aşamasındaki Coğrafi İşaret. http://www.turkpatent.gov.tr/TURKPATENT/geographicalList/ (Erişim Tarihi, 09.02.2018)

Türnüklü, A. (2000). Ĕğitimbilim araştırmalarında etkin olarak kullanılabilecek nitel bir araştırma tekniği: Görüşme. Kuram ve Uygulamada Eğitim Yönetimi. 6(4), 527-542.

Yenipınar, U., Köşker, H. ve Karacaoğlu, S. (2014). Turizmde yerel yiyeceklerin önemi ve coğrafi işaretleme: Van Otlu Peyniri, Journal of Tourism and Gastronomy Studies, 2(2), 13-23.

Yıldırım, A. ve Şimşek, H. (1999). Sosyal bilimlerde nitel araştırma yöntemleri. Ankara: Seçkin Yayınevi.

\section{EXTENDED ABSTRACT}

In recent years, tourism sector that has important contribution to countries in economic sense plays effective role for cultural and traditional value promotion (Orhan, 2010, p. 243). Demand for regional products that increase nature conditions and regional properties for a region or territory, awareness and quality has been rapidly increasing (Schneider \& Ceritoğlu, 2010, p. 30). In this sense, European countries such as France started to apply protection on certain products such as wine in 1992 for the first time and such applications has been shaped within Geographical Indication system at European Union and global scale (Kan, Gülçubuk \& Küçükçongar, 2012, p. 93). Geographical indications are defined as important industrial property right as these indications contribute to regional economy and promote the region (Özkaya, Sünnetçioğlu \& Can, 2013, p. 17) and most importantly, acts as tool to preserve and transfer values of the region to next generations (Tanrikulu, 2011, p. 181).

Purpose of this study is to analyse views of businesses with geographical indication product manufacturing to geographical indication registration and registration certificate. Within this scope, this study is conducted with eight different business managers in dried mulberry rollup and Gümüşhane Kömesi (churchkhela) production businesses which are geographically registered gastronomy products of Gümüşhane city.

Study data are collected with semi-structured interview method of qualitative research techniques. In this technique, researcher prepares interview protocol for planned questions (Türnüklü, 2000, p. 547). On contrary to fully-structured form, semi-interview questions can be altered and additional questions can be asked in this method. This way, limitations on information transferred by interviewed individual can be limited and detailed information about the subject can be achieved (Merriam, 2013, p. 87-88). Main benefit of semi-structured interview technique to researcher is easier systematic and comparable information collection (Yıldırım \& Şimsek, 1999, p. 283).

Based on study purpose, the data of this study were obtained with semi-structured interview technique from the 8 different managers of mullbery fruit leather and Gümüşhane Kömesi (churchkhela) companies in Gümüşhane between 15-25 January 2018. By considering that when qualitative research data reached saturation, i.e., when researcher felt similar topics are mentioned, sufficient participants are reached (Merriam, 2013, p. 207), 8 business owner interview is considered sufficient. The interviews with the participants were conducted between 30-55 minutes.

All interviews in this study are recorded with audio recorder to prevent any data loss. To analyse recorded data, these data are transcribed by the researcher. Descriptive analysis is used to analyse obtained data and analysis of related document. When referring to interviewed individuals, based on participant 
demands, codes are used instead of names. In this sense, businesses and participants are coded as A, B, C, $\mathrm{D}, \mathrm{E}, \mathrm{F}, \mathrm{G}$ and $\mathrm{H}$ letters.

In these interviews, it is determined that all participants except B business owner heard of geographical indication concept and know that Gümüşhane dried mulberry rollup and mulberry molasses is protected under geographical indication registration. Participants express that information related with geographical indication system was periodically provided in meetings organized by Gümüşhane Chamber of Commerce and Industry. Although all participants except B business owner have knowledge on geographical indication system, all participants except A business owner express that they do not use geographical indication registration certificate/logo to sell and promote related goods. This information obtained from interview is supported with information collected from Gümüşhane Special Provincial Directorate of Administration applications for related products. It is determined that there was no application to Gümüşhane Special Provincial Directorate of Administration to use geographical indication registration certificate/logo expect A business.

To analyses views of geographical indication product producer businesses to obtaining geographical indication registration and registration certificate, based on interviews conducted with dried mulberry rollup and Gümüşhane Kömesi (churchkhela) producer business, there is no business that uses geographical indication registration except one business. This finding is one of the most remarkable results of this study. Under current conditions, geographical indication registration certificate leads meaning losses. If a certificate is not applied, such certificate does not serve to a purpose. Business owners should contact to related institutions in the shortest time possible and these owners should be encouraged to use geographical indication registration

Since geographical indication registration is not adopted and used by business, it is stated that improper raw material such as glucose syrup, watered milk, alpha toxin containing ground walnut has been used in geographical indication product (Gümüşhane churchkhela and dried mulberry rollup) production. If necessary precautions are not taken, this can negatively reflect to consumer who prefers and cares about regional gastronomic products as well as producers who want to produce healthy and original products. Studies conducted to measure geographical indication product perception of consumers (Bonnet and Simioni, 2001; Ertan, 2010; Ittersum and Janssen, 2007), it can be seen that since geographical indication tagged products provide sense of trust to consumers, consumers are willing to pay more with added value compared to similar products. Accordingly, with geographical indications, regional economies will have the potential to thrive and added value will be provided to rural development (Ertan, 2010; Mercan and Üzülmez, 2014; Orhan, 2010).

It is seen that in line with not using geographical indication registration of businesses, auditing to protect regional products is insufficient. Auditing problem in geographical indication products are similar with Doğdubay and Sünnetçioğlu (2015) and Taşdan, Albayrak and Albayrak (2014) studies. This lays ground to improper product use in geographical indication local product production. Business should be guided to use registration certification to prepare products that match original properties and to protect consumers who wants to consume healthy and reliable product and businesses to conduct regular auditing. 